\title{
Appropriateness of Gastrointestinal Endoscopy: Risk of Complications ${ }^{1}$
}

\author{
F. Froehlich*, J.-J. Gonvers*, J.-P. Vader**, R. W. Dubois***, B. Burnand** \\ * Policlinique Médicale Universitaire, Lausanne, Switzerland \\ ** Institut Universitaire de Médicine Sociale et Préventive, Lausanne, Switzerland \\ *** Protocare Sciences, Santa Monica, USA
}

\section{Introduction}

An endoscopic procedure is considered appropriate if the benefit for the patient exceeds the risks by a sufficiently wide margin that endoscopy is worth performing.

In November 1998, a multidisciplinary European expert panel convened in Lausanne, Switzerland, to discuss and develop criteria for the appropriate use of gastrointestinal endoscopy, a widely-used procedure, regarded as highly accurate and safe. A detailed description of the RAND appropriateness method, including the literature search process [2], and of the whole process, as well as the global results of the panel [1], are published as separate articles in this issue of the Journal.

The present article on complications of gastrointestinal endoscopy summarises the risks associated with upper and lower gastrointestinal endoscopy. For this purpose, a literature review was conducted, based on a systematic search of Medline, Embase and the Cochrane Library conducted up to the end of 1997 and completed with some key articles published in 1998. Updating and revision of the literature review is currently ongoing.

\section{Literature Review}

Endoscopy has a small, but definite risk of complications, including death. Most data describing complications of endoscopy have been assembled by means of retrospective case reviews from centres performing a large volume of procedures. These studies generally reflect the complication rate recorded by endoscopists with substantial skill and experience, and the rates reported may, therefore, not reflect the experience of a "typical" patient who undergoes an endoscopic procedure performed by a "typical" community-based endoscopist. In addition, there may be a sub- stantial reporting bias in retrospective series. There are, unfortunately, no formal reporting requirements regarding endoscopic complications. Recently, a new system for defining endoscopic complications, emphasising the measure of importance, has been proposed [3].

\section{Cardio-respiratory Complications}

More than $50 \%$ of the morbidity and mortality from diagnostic endoscopic procedures relate to cardio-respiratory complications [4]. Most of these complications are attributable to the use of intra-venous sedation as premedication for endoscopic procedures. Adverse outcomes of upper and lower gastrointestinal endoscopy caused by conscious sedation have been reported with an incidence rate of $0.54 \%$ [5] and fatalities with a rate of $0.03 \%$ [5]. The overall complication rate was $1.35 \%$, including perforation and hemorrhage. Most complications of gastrointestinal endoscopy are of cardio-pulmonary origin as a consequence of hypoxemia which may be related to the procedure itself, to conscious sedation or to a combined effect of both of these [6]. Numerous studies have assessed cardio-respiratory parameters such as oxygen saturation and blood pressure during endoscopy. Significant oxygen desaturation $(<90 \%)$ has been found in 7 to $40 \%$ of gastroscopies [6] and in 13 to $81 \%$ of patients undergoing colonoscopy [7]. Common methodological limitations are, however, apparent in most of these studies, which were either not placebocontrolled, not performed in a double-blind fashion, or which used higher doses of benzodiazepines than is at present recommended. In the USA and the UK, monitoring of oxygen saturation by pulse oxymetry has become standard practice.
Endoscopy 1999; 31 (8): 684-686

C Georg Thieme Verlag Stuttgart - New York ISSN 0013-726X

\footnotetext{
1 The European Panel on Appropriateness of Gastrointestinal Endoscopy (EPAGE, Lausanne, Switzerland)
} 


\section{Procedure-related Complications of Upper and Lower GI Endoscopy}

Table 1 summarises the aggregate complication rates from 32 studies prior to 1981 [8] and in series reported since $1981[4,9-11]$. Mortality rates ranged from 0 to $0.07 \%$, with total morbidity rates from 0.14 to $0.20 \%$ of cases, perforation in 0.01 to $0.2 \%$ of cases, and bleeding in about $0.02 \%$ of cases.

Complication rates for diagnostic colonoscopy are summarised in Table $\mathbf{2}[8,9,12-15]$. Reported mortality rates ranged from 0.02 to $0.06 \%$, with morbidity rates of 0.14 to $0.25 \%$. The most common serious complications of colonoscopy were perforation (up to $0.2 \%$ ) and bleeding (up to $0.11 \%$ ).

Complication rates for therapeutic colonoscopy are shown in Table $3[8,9,13,15-17]$. Mortality rate was up to $0.04 \%$. Bleeding occurred in 0.4 to $3.3 \%$, perforation in 0.04 to $0.5 \%$, and surgery was required in up to $0.42 \%$.

\section{Bacteriemia Resulting from Endoscopy}

About $4 \%$ of patients develop bacteriemia associated with endoscopy, but there have only been a few case reports of significant clinical sequelae $[18-20]$. The American Society for Gastrointestinal Endoscopy recommends antibiotic prophylaxis for ERCP, stricture dilation and varice sclerosis in patients with a history of endocarditis, prosthetic valve or systemic pulmonary shunt, but not unequivocally for other endoscopic procedures. In addition, antibiotic prophylaxis is clearly recommended for obstructed bile ducts and for endoscopic feeding tube placement [21].

\section{Iatrogenic Infection}

Transmission of infectious material via contaminated endoscopes can occur, usually resulting from improper cleaning and disinfection procedures, as well as problems related to equipment design. A review performed in 1993 located 281 reports of infections transmitted by endoscopy [22]. The authors point out that the reported number of cases

Table 1 Complication rates (\%) in patients undergoing diagnostic UGI endoscopy

\begin{tabular}{|c|c|c|c|c|c|c|c|c|}
\hline Reference & $\begin{array}{l}\text { Number of } \\
\text { procedures }\end{array}$ & $\begin{array}{l}\text { Mortality } \\
(\%)\end{array}$ & $\begin{array}{l}\text { Total } \\
(\%)\end{array}$ & $\begin{array}{l}\text { Perforation } \\
\text { (\%) }\end{array}$ & $\begin{array}{l}\text { Morbidity } \\
\text { Bleeding } \\
(\%)\end{array}$ & $\begin{array}{l}\text { Drug } \\
(\%)\end{array}$ & $\begin{array}{l}\text { Cardioresp. } \\
(\%)\end{array}$ & $\begin{array}{l}\text { Other } \\
(\%)\end{array}$ \\
\hline Kahn [8] & 315758 & 0.01 & 0.20 & 0.04 & 0.02 & 0.10 & 0.05 & 0.01 \\
\hline Miller [1 1] & 252858 & 0.005 & & 0.008 & & & 0.73 & \\
\hline Raiertsen [9] & 7314 & 0.04 & 0.14 & 0.01 & 0.06 & & 0.06 & \\
\hline Rodney [10] & 717 & 0 & 0.14 & & & & & \\
\hline
\end{tabular}

Table 2 Complication rates (\%) in patients undergoing diagnostic colonoscopy

\begin{tabular}{|c|c|c|c|c|c|c|c|}
\hline Reference & $\begin{array}{l}\text { Number of } \\
\text { procedures }\end{array}$ & $\begin{array}{l}\text { Mortality } \\
(\%)\end{array}$ & $\begin{array}{l}\text { Total } \\
(\%)\end{array}$ & $\begin{array}{l}\text { Bleeding } \\
(\%)\end{array}$ & $\begin{array}{l}\text { Morbidity } \\
\text { Perforation } \\
(\%)\end{array}$ & $\begin{array}{l}\text { Other } \\
(\%)\end{array}$ & $\begin{array}{l}\text { Surgery } \\
(\%)\end{array}$ \\
\hline Kahn [8] & 85545 & 0.02 & 0.25 & 0.03 & 0.20 & 0.03 & 0.05 \\
\hline Macrae [14] & 5000 & 0.06 & & 0.02 & 0.06 & & \\
\hline Gilbert [12] & 4713 & 0 & & 0.11 & 0.17 & & \\
\hline Hahr-Gama [13] & 3256 & 0 & & 0 & 0.06 & & \\
\hline Reiertsen [9] & 3538 & 0 & 0.14 & 0.03 & & 0.11 & \\
\hline Waye [15] & 1320 & 0 & 0 & 0 & 0 & 0.3 & \\
\hline
\end{tabular}

Table 3 Complication rates (\%) in patients undergoing therapeutic colonoscopy

\begin{tabular}{|c|c|c|c|c|c|c|c|}
\hline Reference & $\begin{array}{l}\text { Number of } \\
\text { procedures }\end{array}$ & $\begin{array}{l}\text { Mortality } \\
(\%)\end{array}$ & $\begin{array}{l}\text { Total } \\
(\%)\end{array}$ & $\begin{array}{l}\text { Bleeding } \\
(\%)\end{array}$ & $\begin{array}{l}\text { Morbidity } \\
\text { Perforation } \\
(\%)\end{array}$ & $\begin{array}{l}\text { Other } \\
(\%)\end{array}$ & $\begin{array}{l}\text { Surgeny } \\
(\%)\end{array}$ \\
\hline Kahn [8] & 25558 & 0.04 & 2.16 & 1.67 & 0.46 & 0.07 & 0.32 \\
\hline Waye [15] & 777 & 0 & 4.8 & 3.3 & 0.3 & & \\
\hline Shiaya [16] & 5500 & 0 & & 0.4 & 0.04 & & \\
\hline Hahr-Gama [13] & 911 & 0 & 0.99 & 0.66 & 0.33 & & \\
\hline Reiertsen [9] & 952 & 0 & 7.2 & 1.2 & 0.5 & 4.5 & 0.42 \\
\hline Nivatonga [17] & 1172 & 0 & 1.2 & 0.6 & & 0.7 & 0.17 \\
\hline
\end{tabular}


probably substantially underestimate the true transmission rate. There were no reports of transmission of HIV infection by endoscopy, although one case of hepatitis B virus transmission was documented. A case of transmission of hepatitis $\mathrm{C}$ virus during colonoscopy was reported very recently [23].

\section{Summary}

The balance between risks and benefits of gastrointestinal endoscopy for a given patient is essential in defining the appropriate use of endoscopic procedures. The current literature suggests that gastrointestinal endoscopy infrequently results in major procedure-related morbidity and mortality, while cardio-respiratory events occur commonly. However, true complication rates may be underestimated due to inconsistencies in the types of complications reported. No formal reporting requirements exist, and most of the published studies on complications come from centres with highly-skilled endoscopists.

\section{Acknowledgement}

This work was supported by the EU BIOMED II Programme (BMH4-CT96-1202), the Swiss National Science Foundation (32.40522.94) and the Swiss Federal Office of Education and Science (95.0306-2).

\section{References}

${ }^{1}$ Vader JP, Burnand B, Froehlich F, Dubois RW, Bochud M, Gonvers JJ. The European Panel on Appropriateness of Gastrointestinal Endoscopy (EPAGE): Project and methods. Endoscopy 1999; 31:572-579

${ }^{2}$ Vader JP, Froehlich F, Dubois RW, Beglinger C, Wietlisbach V, Pittet V, Ebel N, Gonvers JJ, Burnand B. The European Panel on the Appropriateness of Gastrointestinal Endoscopy (EPAGE): Conclusions and WWW site. Endoscopy 1999; 31: 687-694

${ }^{3}$ Fleischer DE, Vandemierop F, Eisen GM, Alkawas FH, Benjamin SB, Lewis JH, Nguyen CC, Avigan M, Kidwell JA. A new system for defining endoscopic complications emphasizing the measure of importance. Gastrointest Endosc 1997; 45: 128133

${ }^{4}$ Hart R, Classen M. Complications of diagnostic gastrointestinal endoscopy. Endoscopy 1990; 22: 229-233

${ }^{5}$ Arrowsmith JB, Gerstman BB, Fleischer DE, Benjamin SB. Results from the American Society for Gastrointestinal Endoscopy/U.S. Food and Drug Administration collaborative study on complication rates and drug use during gastrointestinal endoscopy. Gastrointest Endosc 1991; 37: $421-427$

${ }^{6}$ Froehlich F, Schwizer W, Thorens J, Kohler M, Gonvers JJ, Fried M. Conscious sedation for gastroscopy: patient tolerance and cardiorespiratory parameters. Gastroenterology 1995; 108: 697-704

${ }^{7}$ Froehlich F, Thorens J, Schwizer W. Sedation and analgesia for colonoscopy: patient tolerance, pain, and cardiorespiratory parameters. Gastrointest Endose 1997; 45: 1-9.
${ }^{8} \mathrm{Kahn} \mathrm{K}$. Indications for selected medical and surgical procedures-a literature review and ratings of appropriateness. Diagnostic upper gastrointestinal endoscopy.Santa Moncia, California: The Rand Corporation 1986

${ }^{9}$ Reiertsen O, Skjoto J, Jacobsen CD, Rosseland AR. Complications of fiberoptic gastrointestinal endoscopy-five years' experience in a central hospital. Endoscopy 1987; 19:1-6

${ }^{10}$ Rodney WM, Hocutt JEJr, Coleman WH, Weber JR, Swedberg JA, Cronin C, Gelb DM, Godreau CJ, Bradford CR, Esophagogastroduodenoscopy by family physicians: a national multisite study of 717 procedures (see comments). Journal of the American Board of Family Practice 1990; 3: 73-79

${ }^{11}$ Miller RE, Bossart PW, Tiszenkel HI. Surgical management of complications of upper gastrointestinal endoscopy and esophageal dilation including laser therapy. American Surgeon 1987; 53: $667-671$

${ }^{12}$ Gilbert DA, Hallstrom AP, Shaneyfelt SL, Mahler AK, Silverstein FE, Members of the ASGE. The National ASGE surveycomplications of colonoscopy. Gastrointest Endosc 1984; 30: 156

${ }^{13}$ Habr-Gama A, Waye JD. Complications and hazards of gastrointestinal endoscopy. World J Surg 1989; 13: 193-201

${ }^{14}$ Macrae FA, Tan KG, Williams CB. Towards safer colonoscopy: a report on the complications of 5000 diagnostic or therapeutic colonoscopies. Gut 1983; 24: 376-383

${ }^{15}$ Waye JD, Lewis BS, Yessayan S. Colonoscopy: a prospective report of complications. J Clin Gastroenterol 1992; 15: 347351

${ }^{16}$ Shinya $\mathrm{H}$. Complications: prevention and management. In colonoscopy: diagnostic and treatment of colonic diseases. New York: Igaku-Shoin 1982: 199-208

${ }^{17}$ Nivatvonga S. Complications in colonoscopic polypectomy. An experience with 1555 polypectomies. Dis Colon Rectum 1986: 29: $825-830$

${ }^{18}$ Kelley CJ, Ingoldby CJ, Blenkharn JI, Wood CB. Colonoscopy related endotoxemia. Surgery, Gynecology \& Obstetrics 1985; 161: $332-334$

${ }^{19}$ London MT, Chapman BA, Faoagali JL, Cook HB. Colonoscopy and bacteraemia: an experience in 50 patients. New Zealand Medical Journal 1986; 99: 269-271

${ }^{20}$ Shorvon PJ, Eykyn SJ, Cotton PB. Gastrointestinal instrumentation, bacteraemia, and endocarditis. (Review $110 \mathrm{refs}$ ). Gut 1983; 24: 1078-1093

${ }^{21}$ ASGE. Antibiotic prophylaxis for gastrointestinal endoscopy. American Society for Gastrointestinal Endoscopy. Gastrointest Endose 1995; 42: 630-635

${ }^{22}$ Spach DH, Silverstein FE, Stamm WE. Transmission of infection by gastrointestinal endoscopy and bronchoscopy. Ann Intern Med 1993; 118: $117-128$

${ }^{23}$ Kozarek RA. Transmission of hepatitis $\mathrm{C}$ virus during colonoscopy. N Engl J Med 1997; 337; 1848-1849

\section{Corresponding Author}

Florian Froehlich, MD, PD

Senior Lecturer in Gastroenterology

Policlinique Médicale Universitaire

Rue César-Roux 19

CH-1005 Lausanne

Switzerland

Fax: $\quad+41-32-4662955$

E-mail: florian.froehlich@bluewin.ch 